\title{
Histopathological and ultrastructural features of enlarged cells of humpback grouper Cromileptes altivelis challenged with Megalocytivirus (family Iridoviridae) after vaccination
}

\author{
Ketut Mahardika ${ }^{1}$, Haryanti $^{2}$, Ahmad Muzaki ${ }^{2}$, Teruo Miyazaki ${ }^{1, *}$ \\ ${ }^{1}$ Graduate school of Bioresources, Mie University, Tsu, Mie 514-8507, Japan \\ ${ }^{2}$ Gondol Research Institute for Mariculture, PO Box 140, Singaraja, Bali Island, Indonesia
}

\begin{abstract}
The genus Megalocytivirus in the family Iridoviridae encompasses isolates of red sea bream iridovirus (RSIV) and grouper sleepy disease iridovirus (GSDIV). In the present study, humpback grouper Cromileptes altivelis juveniles were challenged with GSDIV after vaccination with a commercial RSIV vaccine. The unvaccinated group (in duplicate) showed higher mortalities (59.3 to $66.7 \%$ ) than the vaccination group ( $0 \%$ mortalitiy, in duplicate). Surviving fish in the vaccinated group displayed masses of enlarged cells in the spleen. Electron microscopy revealed that they contained hemosiderin granules within the cytoplasm. In contrast, moribund fish from the unvaccinated group exhibited large numbers of inclusion body-bearing cells (IBCs) in the spleen, while surviving fish displayed masses of enlarged cells in which a small number of GSDIV virions were assembled.
\end{abstract}

KEY WORDS: Humpback grouper · Cromileptes altivelis $\cdot$ Commercial RSIV vaccine $\cdot$ Grouper sleepy disease iridovirus $\cdot$ Enlarged cells

Resale or republication not permitted without written consent of the publisher

\section{INTRODUCTION}

The genus Megalocytivirus in the family Iridoviridae encompasses several viral isolates such as grouper sleepy disease iridovirus (GSDIV), red sea bream iridovirus (RSIV), sea bass iridovirus (SBIV), African lampeye iridovirus (ALIV), dwarf gourami iridovirus (DGIV), Taiwan grouper iridovirus (TGIV) and infectious spleen and kidney necrosis virus (ISKNV), which are genetically identical (Chinchar et al. 2005). In Indonesia, groupers Epinephelus spp. are major mariculture fish species, and in recent years, with the rapidly developing aquaculture industries, viral diseases have caused severe epizootics resulting in mass mortalities and large-scale economic losses. GSDIV has caused mass mortality in orange-spotted grouper E. coioides cultured in pen-cages off North-Sumatra
Island (Koesharyani et al. 2001) and orange-spotted grouper E. coioides and Bleeker's grouper E. bleekeri cultured in pens offshore of Bali Island (Mahardika et al. 2001). GSDIV has also been shown to infect other groupers such as the humpback grouper Cromileptes altivelis (Mahardika et al. 2004), tiger grouper E. fuscoguttatus and marbled grouper E. polyphekadion (K. Mahardika unpubl. data). In ornamental freshwater fishes, megalocytivirus has also been isolated from diseased African lampeye Aplocheilichthys normani, which were cultured on Sumatra Island and exported to Japan (Sudthongkong et al. 2002a), and diseased dwarf gourami Colisa lalia, which were exported to Australia from southeast Asia (Go \& Whittington 2006). Moreover, megalocytivirus diseases have also been found in both marine and freshwater fishes in other Asian countries (Inouye et al. 1992, 
Chua et al. 1994, Matsuoka et al. 1996, Danayadol et al. 1997, Kasornchandra \& Khongpradit 1997, Chou et al. 1998, Jung \& Oh 2000, Chao et al. 2002, Kawakami \& Nakajima 2002, Sano et al. 2002, Sudthongkong et al. 2002b, Weng et al. 2002, Chen et al. 2003, GibsonKueh et al. 2003, Shi et al. 2004). A diagnostic feature of megalocytivirus disease is the formation of inclusion body-bearing cells (IBCs) as well as necrotized cells, both of which are observed as enlarged cells by light microscopy (Miyazaki 2007).

Recently, a commercialized formalin-inactivated RSIV vaccine has been shown to be highly efficient in protecting vaccinated red sea bream Pagrus major and other cultured marine fishes against RSIV disease (RSIVD) (Nakajima et al. 1997, 2002). However, the ultrastructural features of fish vaccinated against megalocytivirus were not investigated.

In order to compare histopathological changes in unvaccinated, surviving fish after challenge with GSDIV with changes in surviving fish after being vaccinated and challenged with GSDIV, we undertook vaccination trials using a commercialized formalininactivated RSIV vaccine 'Biken' (The Research Foundation for Microbial Diseases of Osaka University, Kagawa, Japan). The present study describes the results of the vaccination test and ultrastructural features of the enlarged cells that developed in surviving fish of the vaccinated and unvaccinated groups.

\section{MATERIALS AND METHODS}

Experimental fish. For vaccination experiments, a total of 120 humpback grouper (mean body weight, $5 \mathrm{~g}$ ) were obtained from a fish breeder in Bali Island. Ten samples of these were examined by PCR assay using a primer set for SJNNV (striped jack nervous necrosis virus) (Nishizawa et al. 1994) and for Pst I restriction fragment of RSIV genomic DNA (Kurita et al. 1998), and all were negative for the presence of NNV (nervous necrosis virus: Betanodavirus) and megalocytivirus.

Virus stock. The GSDIV stock used in the experimental infections was derived from the spleens of tiger groupers that were experimentally infected with a spleen filtrate, which originated from orange-spotted groupers with grouper sleepy disease (GSD). The spleens were stored at $-80^{\circ} \mathrm{C}$ after all of the spleen samples were confirmed positive for GSDIV by PCR ('PCR analysis'; see below). For the challenge tests the spleen tissue was homogenized in 10x vol of phosphatebuffered saline (PBS, pH 7.4) in a glass homogenizer. The homogenate was centrifuged at $3000 \times g$ for $5 \mathrm{~min}$ at $4^{\circ} \mathrm{C}$, and the supernatant was harvested and filtered $(450 \mathrm{~nm})$. To determine the appropriate challenge dose for the vaccination trials, a pilot experiment was conducted using 3 dilutions of this GSDIV preparation, injected intramuscularly (i.m.), $0.1 \mathrm{ml}$ per fish, 5 fish per group.

Vaccination and challenge tests. One experiment was conducted with duplicate tanks (27 to 28 fish per tank) for each of the vaccinated and unvaccinated (control) groups. The vaccinated fish were injected (i.m.) with $0.1 \mathrm{ml}$ of the formalin-inactivated RSIV vaccine 'Biken', according to the manufacturer's protocol. The unvaccinated fish were injected (i.m.) with the same amount of Eagle's minimum essential medium (EMEM) supplemented with $2 \%$ fetal bovine serum. The fish were held in tanks (200 lat 28 to $31^{\circ} \mathrm{C}$ ) with aeration and daily water exchange. Ten days post-vaccination, all fish were challenged (i.m.) with $0.1 \mathrm{ml}$ of a $10^{-1}$ dilution of GSDIVpositive spleen filtrate and were monitored for $17 \mathrm{~d}$. Moribund and dead fish were removed from the tanks, dissected and samples were processed for laboratory examination. At the end of the experiment, all surviving fish were dissected for subsequent laboratory examination. Tissue samples of 26 moribund fish, 16 surviving fish in the unvaccinated group and 27 surviving fish in the vaccinated group were fixed in Bouin's fluid $(15 \mathrm{ml}$ picric acid, $5 \mathrm{ml}$ of $37 \%$ formaldehyde solution containing $8 \%$ methanol, $1 \mathrm{ml}$ acetic acid) for histological examination. Further samples of the spleen tissue were fixed in $70 \%$ Karnovsky's solution (1.6 g paraformaldehyde in $20 \mathrm{ml}$ distilled water, $2 \mathrm{ml}$ of $70 \%$ glutaraldehyde, $35 \mathrm{ml}$ of $0.2 \mathrm{M}$ PBS, $13 \mathrm{ml}$ distilled water), post-fixed in $1 \%$ $\mathrm{OsO}_{4}$ and processed for examination by electron microscopy.

PCR analysis. PCR analysis to test for the presence of GSDIV in fish tissues was undertaken using primers 1-F (5'-CTCAAACACTCTGGCTCATC-3') and 1-R (5'-GCACCAACACATCTCCTATC-3'), which were derived from the DNA sequence of the 959-bp PstI fragment of RSIV (Kurita et al. 1998). Using this PCR test, amplification products of ca. $570 \mathrm{bp}$ were generated. In adddition to the viral inoculum, the spleens of 10 surviving fish in the vaccinated group, and 10 dead and 10 surviving fish in the unvaccinated group, were processed for PCR analysis. DNA templates were extracted from ca. $10 \mathrm{mg}$ of spleen tissue using ISOGEN (Wako Nippon Gene) according to the manufacturer's protocol. The PCR amplification was performed under conditions described previously by Kurita et al. (1998).

\section{RESULTS AND DISCUSSION}

In the pilot experiment of the present study, inoculation of a $10^{-1}$ dilution of the GSDIV stock into experimental fish resulted in ca. $60 \%$ mortality and was determined to be the appropriate dilution for the vacci- 
nation trials. In the vaccination trials, as expected, mortality in the unvaccinated group began $8 \mathrm{~d}$ after challenge with GSDIV, reaching plateaus of 59.3 and $66.7 \%$ in the duplicate tanks within $13 \mathrm{~d}$. In contrast, 0 mortality occurred in the vaccinated fish. Diseased fish usually displayed loss of appetite and sleepy behavior indicated by lying on a pectoral fin and subsequently lying on their side just before death. All moribund fish displayed a slight dark coloration of the body surface and a markedly swollen spleen. The surviving fish in the unvaccinated group and vaccinated group did not display sleepy behavior and maintained a good appetite throughout the experimental period.

Of the surviving, vaccinated fish (a total of 27), histopathology was mainly observed in the spleen. Multiple cellular masses comprised of increased numbers of enlarged cells, many of which contained brown-colored hemosiderin pigmentation, and a few others had a pale cytoplasm (Table 1, Fig. 1a). The same masses of enlarged cells were also found in the hematopoietic tissue of the kidney. No histopathology was observed in the gill, liver, heart or digestive tracts.

Of the 26 moribund fish in the unvaccinated group, all spleens contained many IBCs as well as necrotized cells with large numbers of GSDIV virions within the splenic pulps and ellipsoids (Table 1, Fig. 1b). In the kidney many IBCs appeared in the hematopoietic tissues. The gill, liver, heart and digestive tracts contained a few IBCs. In contrast, the spleen and kidney of 16 surviving fish in the unvaccinated group exhibited large numbers of masses comprised of many enlarged cells with a pale cytoplasm, and a few other cells contained brown hemosiderin pigments (Table 1, Fig. 1c,d). A few masses of enlarged cells were found in
Table 1. Cromileptes altivelis. Histopathological signs of humpback grouper challenged with grouper sleepy disease iridovirus (GSDIV) after vaccination. Signs occurred in the spleen and the hematopoietic tissue of kidney. IBCs: inclusion body-bearing cells

\begin{tabular}{|lcrrrc|}
\hline Group & No. of fish & & \multicolumn{3}{c|}{ Histopathological signs } \\
& examined & IBCs & $\begin{array}{c}\text { Masses of } \\
\text { enlarged } \\
\text { cells }\end{array}$ & $\begin{array}{c}\text { Hemosiderin } \\
\text { deposition in } \\
\text { enlarged cells }\end{array}$ \\
\hline Vaccinated & Survivor & 11 & 0 & 11 & 11 \\
Unvaccinated & Moribund & 14 & 14 & 0 & 0 \\
& Survivor & 10 & 0 & 10 & 10 \\
2 Vaccinated & Survivor & 16 & 0 & 16 & 16 \\
Unvaccinated & Moribund & 12 & 12 & 0 & 0 \\
& Survivor & 6 & 0 & 6 & 6 \\
\hline
\end{tabular}
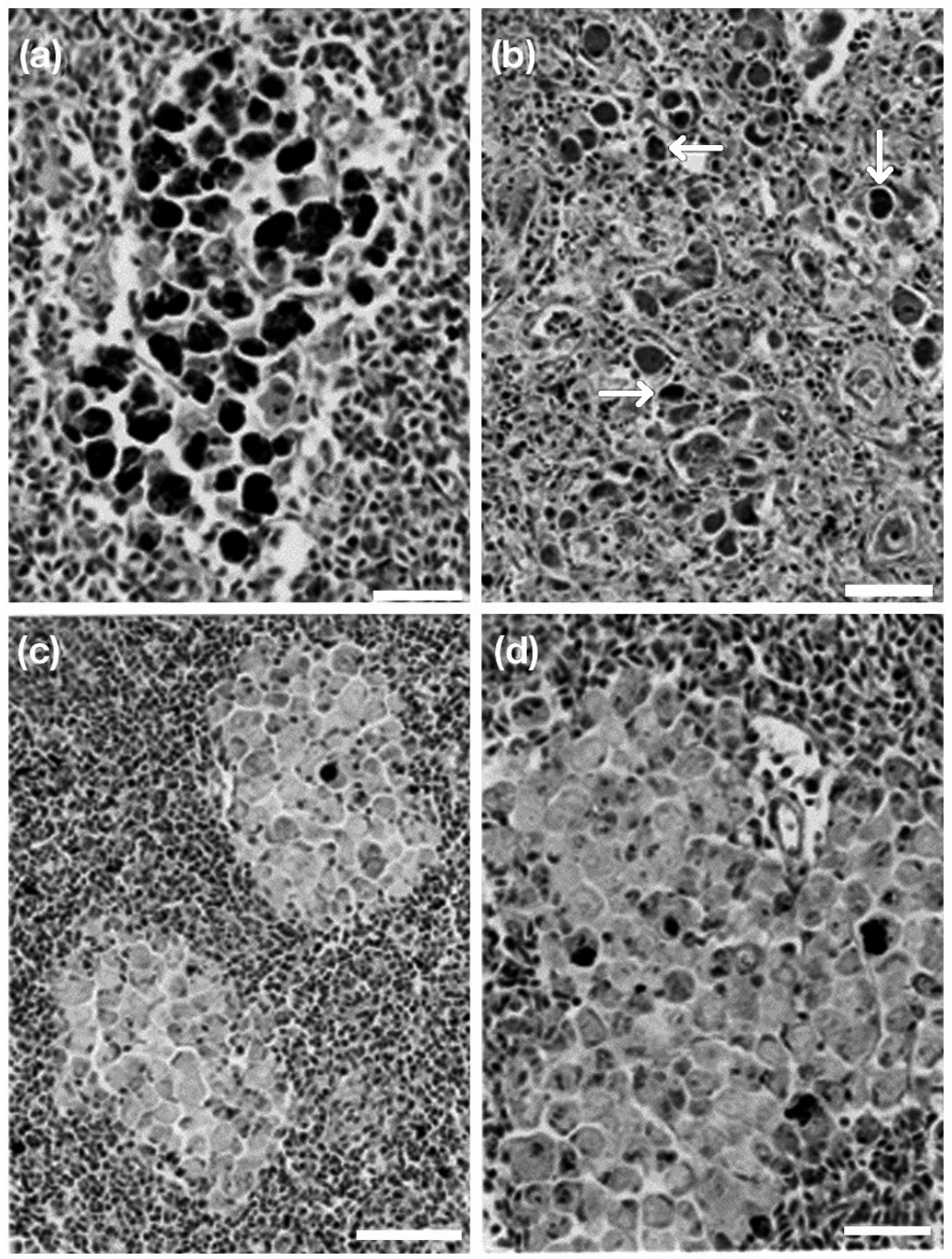

Fig. 1. Cromileptes altivelis. (a) Spleen of surviving humpback grouper from the vaccinated group shows a mass of enlarged cells, many of which contain hemosiderin pigments, while others have a pale cytoplasm (H\&E, scale bar $=25 \mu \mathrm{m})$. (b) Spleen of moribund fish in the unvaccinated group shows many inclusion body-bearing cells (IBCs) and necrotic cells in splenic pulps. Arrows point to mature IBCs $(H \& E$, scale bar $=25 \mu \mathrm{m})$. (c) Spleen of surviving fish in the unvaccinated group displaying masses of enlarged cells with a pale cytoplasm (H\&E, scale bar $=50 \mu \mathrm{m})$. (d) Spleen of surviving fish in the unvaccinated group exhibiting a large mass of enlarged cells with a pale cytoplasm and enlarged cells containing hemosiderin granules $(\mathrm{H} \& \mathrm{E}$, scale bar $=25 \mu \mathrm{m})$ 

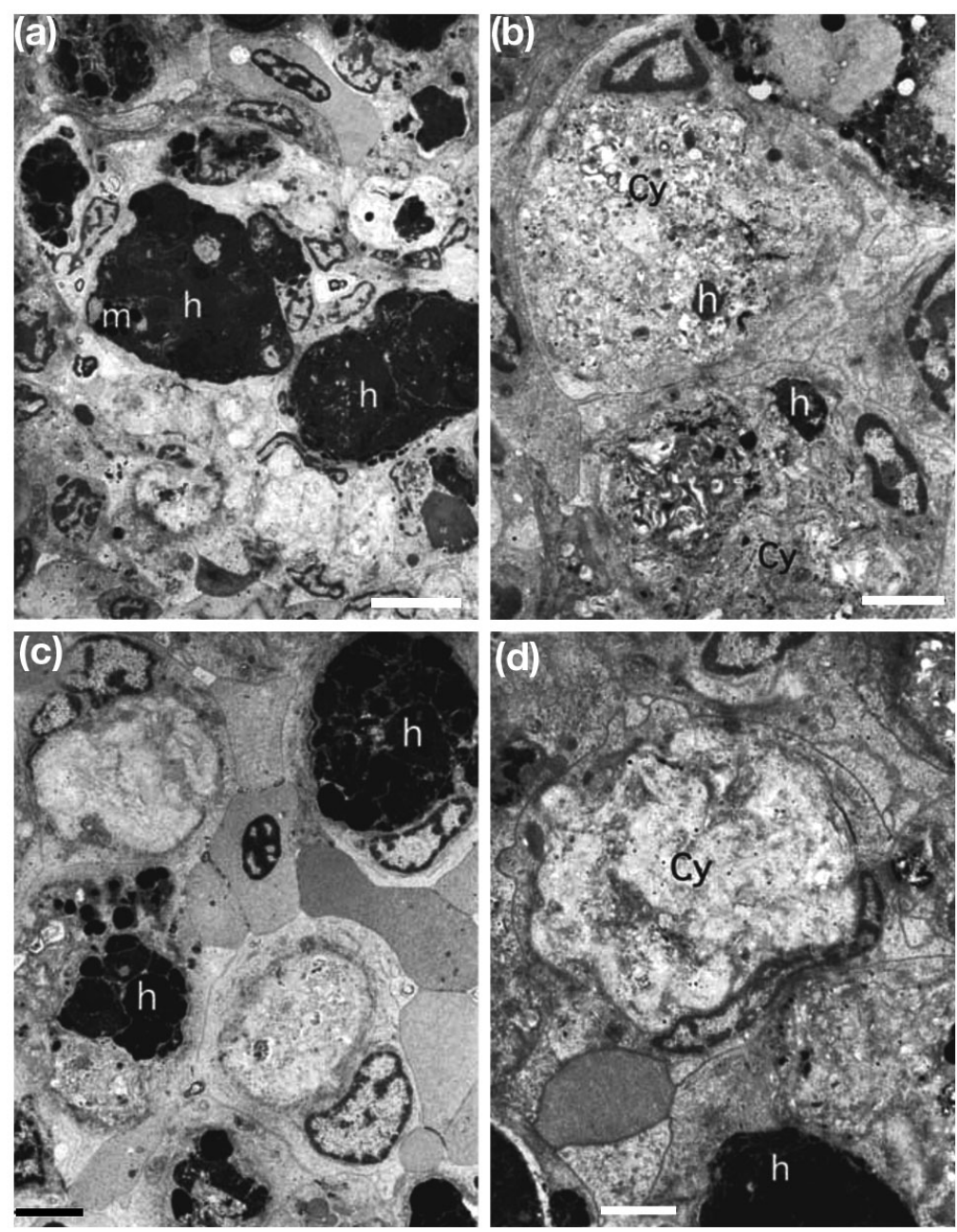

Fig. 2. Cromileptes altivelis. Electron micrographs of enlarged cells of humpback grouper survivors from vaccinated group. (a) Enlarged cells contain hemosiderin granules (h) comprising electron-dense iron granules within cytoplasm, which varies in amount. One cell also contains melanin granules $(\mathrm{m})$ (scale bar $=5200 \mathrm{~nm}$ ). (b) Detail reveals an amorphous matrix containing residual hemosiderin granules (h), myelin-like structures and scattered iron granules (scale bar $=2900 \mathrm{~nm}$ ). (c) An enlarged cell contains a large amount of hemosiderin granules. Other enlarged cells without hemosiderin granules show few mitochondria and rough endoplasmic reticulum (scale bar $=3000 \mathrm{~nm})$. (d) Detail reveals the cytoplasm containing unidentifiable structures and scattered iron granules (scale bar = $1800 \mathrm{~nm})$. Cy: cytoplasm the liver, but no masses of enlarged cells were found in the gill, heart or digestive tracts.

Electron microscopic (EM) examination of the spleen of surviving fish in the vaccinated group revealed enlarged cells and cells containing hemosiderin granules comprising electron-dense iron granules within the cytoplasm. The amount of deposited hemosiderin varied in the cells, some of which also contained melanin granules (Fig. 2). In the cells containing a large amount of hemosiderin, the cytoplasm was mostly filled with hemosiderin granules, and the remaining part of the cytoplasm contained a few mitochondria and rough endoplasmic reticulum (rER). Other hemosiderin-laden cells appeared and contained residual hemosiderin granules, fibrous structures, myelin-like structures and scattered iron granules (Fig. 2b). Other enlarged cells formed an amorphous matrix with a few mitochondria and rER (Fig. 2c). Some enlarged cells had unidentifiable structures with scattered iron granules (Fig. 2d). Viral particles were not observed.
In the unvaccinated group, EM examination of the spleen of moribund fish revealed various IBCs, which were the same as those shown in our previous study (Mahardika et al. 2004). In addition, EM examination of the masses of enlarged cells in surviving fish revealed they had a vacuolated amorphous matrix and contained a small number of GSDIV virions, fibrous structures, myelin-like structures and masses of fine granules, while organelles such as mitochondria and rER were rare (Fig. 3a-c). Assembled virions were round rather than hexagonal with an electron-dense core (Fig. 3d). Some of the enlarged cells contained hemosiderin granules comprised of electron-dense iron granules within the cytoplasm.

A tissue filtrate of virus-infected fish is often used in infection experiments to determine viral pathogenicity and fish susceptibility to disease. In the present study, we used a spleen filtrate of GSDIV-infected fish for the challenge test because in vitro virus culture was not available. The viral inoculum prepared from grouper spleen contained megalocytivirus based on PCR assays 
Fig. 3. Cromileptes altivelis. Electron micrographs of humpback grouper enlarged cells in survivors in the unvaccinated group. (a) Enlarged cells with vacuolated amorphous matrix structures within cytoplasm and other enlarged cells contain hemosiderin granules (h) comprising electron-dense iron granules within the cytoplasm (scale bar $=2300 \mathrm{~nm}$ ). (b) Detail reveals a vacuolated amorphous matrix containing a small number of grouper sleepy disease iridovirus (GSDIV) virions (arrow), few mitochondria and little rough endoplasmic reticulum (scale bar $=800$ $\mathrm{nm}$ ). (c) High-power view of the cytoplasm of an enlarged cell. It contains the vacuolated amorphous matrix with an assembly of deformed virions and scattered iron granules (scale bar $=600 \mathrm{~nm}$ ). (d) Highpower view of a vacuolated amorphous matrix reveals an assembly of deformed and incomplete virions (scale bar = $400 \mathrm{~nm})$. Cy: cytoplasm
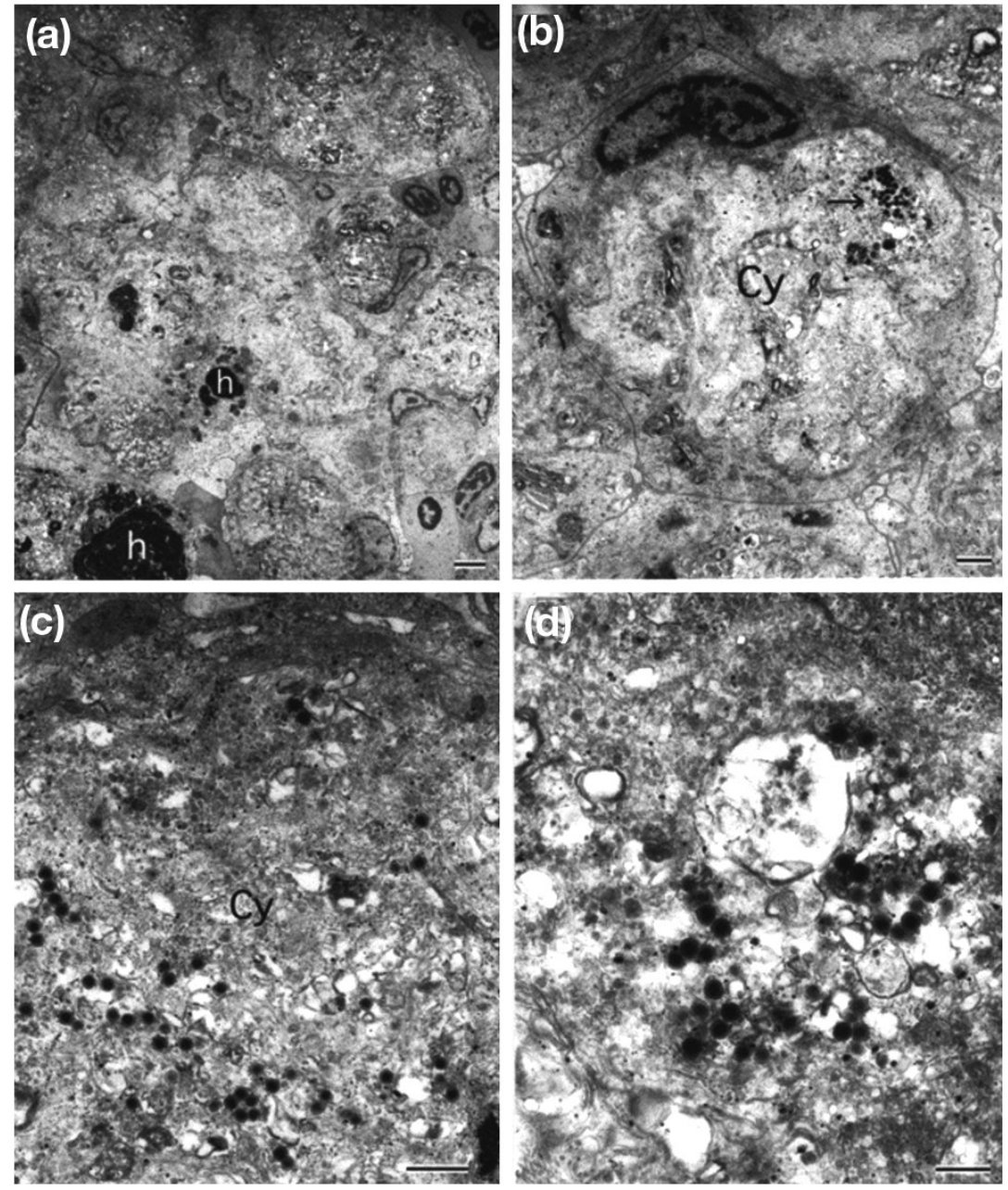

using the primer set that were derived from a Pst I restriction fragment of RSIV genomic DNA (Kurita et al. 1998). Sudthongkong et al. (2002b) have confirmed that GSDIV is the same isolate as RSIV based on homology of ATPase and major capsid protein (MCP) genes. Taking those data and the observed sleepy behavior, the causative megalocytivirus was confirmed to be GSDIV.

Electron microscopy revealed virus particles present in IBCs of moribund fish and enlarged cells of surviving fish in the unvaccinated group. PCR amplicons of the predicted size were derived from the DNA extracts of the spleens of 10 moribund fish and 10 surviving fish from the unvaccinated group, indicating they were virions of GSDIV. On the other hand, PCR products were not obtained from the 10 surviving fish that were examined from the vaccinated group. The formalininactivated RSIV vaccine has been shown previously to confer high levels of protection against RSIV disease in red sea bream Pagrus major (Nakajima et al. 1997), yellowtail Seriola quinqueradiata, amberjack $S$. du- merili, kelp grouper Epinephelus moara, striped jack Pseudocaranx dentex and spotted parrot fish Oplegnathus punctatus under laboratory conditions (Nakajima et al. 2002). Moreover, it has been shown that vaccination of fish with an RSIV vaccine triggers a specific immune response as indicated by an enhanced expression of major histocompatibility complex (MHC) class I and increased levels of serum neutralization antibodies (Caipang et al. 2006). The results from our present study confirmed that the RSIV vaccine was effective against GSDIV infection in humpback grouper, resulting in no mortality in the vaccinated group.

Acknowledgements. We thank all staff of the Biotechnology Laboratory, Gondol Research Institute for Mariculture, Bali Island, Indonesia, for their assistance with the vaccination experiments.

\section{LITERATURE CITED}

Caipang CMA, Hirono I, Aoki T (2006) Immunogenicity, retention and protective effects of the protein derivates of formalin-inactivated red sea bream iridovirus (RSIV) 
vaccine in red sea bream Pagrus major. Fish Shellfish Immunol 20:597-609

Chao CB, Yang SC, Tsai HY, Chen CY, Lin CS, Huang HT (2002) A nested PCR for the detection of grouper iridovirus in Taiwan (TGIV) in cultured hybrid grouper giant seaperch and largemouth bass. J Aquat Anim Health 14:104-113

Chen XH, Lin KB, Wang XW (2003) Outbreaks of an iridovirus disease in maricultured large yellow croaker Larimichthys crocea (Richardson) in China. J Fish Dis 26:615-619

Chinchar G, Essbauer S, He JG, Hyatt A, Miyazaki T, Seligy V, Williams T (2005) Family Iridoviridae. In: Fauquet CM, Mayo MA, Maniloff J, Desselberger U, Ball LA (eds) Virus taxonomy. Classification and nomenclature of viruses. Eighth report of the International Committee on the Taxonomy of Viruses. Academic Press, San Diego, CA, p 145-162

Chou HY, Hsu CC, Peng TY (1998) Isolation and characterization of a pathogenic iridovirus from cultured grouper Epinephelus sp. in Taiwan. Fish Pathol 33:201-206

Chua FHC, Ng ML, Ng KL, Loo IJ, Wee JY (1994) Investigation of outbreaks of a novel disease, 'sleepy grouper disease', affecting the brown-spotted grouper Epinephelus tauvina Forskal. J Fish Dis 17:417-427

Danayadol Y, Direkbusarakom S, Boonyaratpalin S, Miyazaki T, Miyata M (1997) Iridovirus infection in brown-spotted grouper Epinephelus malabaricus cultured in Thailand. In: Flegel TW, MacRae IH (eds) Diseases in Asian aquaculture III. Asian Fisheries Society, Manila, p 67-72

Gibson-Kueh S, Netto P, Ngoh-Lim GH, Chang SF and others (2003) The pathology of systemic iridoviral disease in fish. J Comp Pathol 129:111-119

Go J, Whittington R (2006) Experimental transmission and virulence of a Megalocytivirus (Family Iridoviridae) of dwarf gourami Colisa lalia from Asia in Murray cod Maccullochella peelii peelii in Australia. Aquaculture 258:140-149

Inouye K, Yamano K, Maeno Y, Nakajima K, Matsuoka M, Wada Y, Sorimachi M (1992) Iridovirus infection of cultured red sea bream Pagrus major. Fish Pathol 27:19-27

Jung SJ, Oh MJ (2000) Iridovirus-like infection associated with high mortalities of striped beakperch Oplegnathus fasciatus (Temminck et Schlegel) in southern coastal areas of the Korean peninsula. J Fish Dis 23:223-226

Kasornchandra J, Khongpradit R (1997) Isolation and preliminary characterization of a pathogenic iridovirus in nursing grouper Epinephelus malabaricus. In: Flegel TW, MacRae IH (eds) Diseases in Asian aquaculture III. Asian Fisheries Society, Manila, p 61-66

Kawakami H, Nakajima K (2002) Cultured fish species affected by red sea bream iridoviral disease from 1996 to 2000. Fish Pathol 37:45-47

Koesharyani I, Roza D, Mahardika K, Johnny F Zafran, Yuasa

Editorial responsibility: Mark Crane,

Geelong, Victoria, Australia
K (2001) Marine fish and crustacean diseases in Indonesia. In: Sugama K, Hatai K, Nakai T (eds) Manual for fish disease diagnosis. II. Gondol Marine Research for Mariculture and Japan International Cooperation Agency, Bali, p 5-7

Kurita J, Nakajima K, Hirono I, Aoki T (1998) Polymerase chain reaction (PCR) amplification of DNA of red sea bream iridovirus (RSIV). Fish Pathol 33:17-23

Mahardika K, Koesharyani I, Sugama K, Priyono A, Yuasa K (2001) Histopathological study of iridovirus infection in Epinephelus coioides and Epinephelus bleekeri. Proc Maricul Technol Sea Farming Dev. Japan International Cooperation Agency, Jakarta, p 334-341 (in Indonesian with English abstract)

Mahardika K, Zafran, Yamamoto A, Miyazaki T (2004) Susceptibility of juvenile humpback grouper Cromileptes altivelis to grouper sleepy disease iridovirus (GSDIV). Dis Aquat Org 59:1-9

Matsuoka S, Inouye K, Nakajima K (1996) Cultured fish species affected by red sea bream iridoviral disease from 1991 to 1995. Fish Pathol 31:233-234

Miyazaki T (2007) Color atlas of fish histopathology, Vol 2. Shin-Suisan Shinbun-Sha, Tokyo, p 220-242

Nakajima K, Maeno Y, Kurita J, Inui Y (1997) Vaccination against red sea bream iridoviral disease in red sea bream. Fish Pathol 32:205-209

Nakajima K, Ito T, Kurita J, Kawakami H and others (2002) Effectiveness of a vaccine against red sea bream iridoviral disease in various cultured marine fish under laboratory conditions. Fish Pathol 37:90-91

Nishizawa T, Mori K, Nakai T, Furusawa I, Muroga K (1994) Polymerase chain reaction (PCR) amplification of RNA of striped jack nervous necrosis virus (SJNNV). Dis Aquat Org 18:103-107

Sano M, Minagawa M, Nakajima K (2002) Multiplication of red sea bream iridovirus (RSIV) in the experimentally infected grouper Epinephelus malabaricus. Fish Pathol 37:163-168

Shi CY, Wang YG, Yang SL, Huang J, Wang QY (2004) The first report of an iridovirus-like agent infection in farmed turbot Scophthalmus maximus in China. Aquaculture 236:11-25

Sudthongkong C, Miyata M, Miyazaki T (2002a) Iridovirus disease in two ornamental tropical freshwater fishes: African lampeye and dwarf gourami. Dis Aquat Org 48: 163-173

Sudthongkong C, Miyata M, Miyazaki T (2002b) Viral DNA sequences of genes encoding the ATPase and the major capsid protein of tropical iridovirus isolates, which are pathogenic to fishes in Japan, South China Sea and southeast Asian countries. Arch Virol 147:2089-2109

Weng SP, Wang YQ, He JG, Deng M and others (2002) Outbreaks of an iridovirus in red drum Sciaenops ocellata (L.) cultured in southern China. J Fish Dis 25:681-685

Submitted: May 29, 2007; Accepted: January 18, 2008

Proofs received from author(s): March 14, 2008 